\title{
KEBIJAKAN PENANGGULANGAN TINDAK PIDANA PENEBANGAN LIAR DI WILAYAH KESATUAN PEMANGKUAN HUTAN RANDUBLATUNG
}

\author{
Cahyo Nugroho, Henny Susilowati dan Wiwit Ariyani \\ Email : cahyo_n@gmail.com, henny.susilowati@umk.ac.id, wiwit.ariyani@umk.ac.id \\ Fakultas Hukum Universitas Muria Kudus
}

\begin{abstract}
ABSTRAK
Penelitian dengan judul "Kebijakan Penanggulangan Tindak Pidana Penebangan Liar di Wilayah Kesatuan Pemangkuan Hutan Randublatung" bertujuan untuk mengetahui latar belakang terjadinya peningkatan tindak pidana penebangan liar, mengetahui kebijakan penanggulangan tindak pidana penebangan liar, dan mengetahui hambatan yang dihadapi dalam menanggulangi tindak pidana penebangan liar di wilayah KPH Randublatung. Hasil penelitian menunjukkan tindak pidana penebangan liar meningkat dari tahun ke tahun disebabkan permintaan pasar terhadap kayu sangat tinggi, jumlah Polisi Kehutanan tidak sebanding dengan luas hutan, ekonomi penduduk rendah dan banyaknya pengangguran, pendidikan penduduk rendah, serta lemahnya penegakan hukum terhadap pelaku tindak pidana penebangan liar. Kebijakan penanggulangan tindak pidana penebangan liar di wilayah KPH Randublatung dilakukan dengan 2 (dua) sarana, yaitu sarana non penal dan sarana penal. Sarana non penal terdiri dari 2 (dua) pola, yaitu pola preemtif dan pola preventif. Sarana penal menggunakan pola represif. Hambatan yang dihadapi KPH Randublatung dalam menanggulangi tindak pidana penebangan liar terdiri dari hambatan internal dan hambatan eksternal.
\end{abstract}

Kata Kunci : Kebijakan Penanggulangan, Penebangan Liar, Hutan, Randublatung 


\section{PENDAHULUAN}

Hutan sebagai sumber kekayaan alam yang dimiliki oleh bangsa Indonesia merupakan salah satu modal dasar bagi pembangunan nasional yang dipergunakan untuk meningkatkan kemakmuran rakyat, sehingga seluruh rakyat dapat menikmati hasil-hasil dari sumber daya alam secara adil dan merata. Sebagaimana telah dijelaskan dalam Pasal 33 Ayat (3) UndangUndang Dasar Negara Republik Indonesia Tahun 1945 (selanjutnya disebut UUD Tahun 1945) yang menyatakan bahwa "bumi, air, dan kekayaan alam yang terkandung di dalamnya dikuasai oleh Negara dan dipergunakan untuk sebesar-besarnya kemakmuran rakyat".

Kabupaten Blora adalah kabupaten yang terletak di ujung timur wilayah Provinsi Jawa Tengah. Kabupaten Blora merupakan daerah penghasil kayu jati dengan kualitas terbaik di Indonesia bahkan terkenal sampai mancanegara sehingga mendapat julukan sebagai kota jati. ${ }^{86}$ Seperti di wilayah Kabupaten Blora yang memiliki wilayah hutan cukup luas yaitu $80.586,38$ ha yang terbagi menjadi 3 kesatuan pemangkuan hutan (selanjutnya disebut $\mathrm{KPH}$ ) terdiri dari KPH Randublatung (32.464,1 ha), KPH Cepu (33.017,29 ha) dan KPH Blora $(15.104,99 \mathrm{ha})$ yang komoditi hasil hutan terbesarnya adalah kayu jati. Kondisi ini menyebabkan tindak pidana penebangan liar cukup marak terjadi di wilayah Kabupaten Blora.

Pada tahun 2015 di Kabupaten Blora ada 309 (tiga ratus sembilan) kasus, tahun 2016 ada 320 (tiga ratus

\footnotetext{
86 Anthonie, "Wawancara Pribadi", Wakil Kepala Administratur KPH Blora, 30 Oktober 2017, Pukul 09.00-10.00 WIB.
}

dua puluh) kasus, tahun 2017 ada 532 (lima ratus tiga puluh dua) kasus penebangan liar yang terjadi. Selain itu jumlah pohon yang ditebang juga meningkat dari tahun 2015 sejumlah 1.253, tahun 2016 sejumlah 1.615, dan tahun 2017 sampai bulan september sejumlah 4.112 pohon. $^{87}$

Berikut adalah data terakhir tahun 2017 tentang penebangan liar yang terjadi di wilayah Kabupaten Blora: ${ }^{88}$ di KPH Randublatung ada 619 kejadian, 54 penangkapan, 66 tersangka, jumlah pohon 4508 dan kerugian ditaksir Rp. 6,1 M, di KPH Blora ada 140 kejadian, 2 penangkapan, 2 tersangka, jumlah pohon 480 dan kerugian ditaksir Rp. 0,24 M, sedangkan di KPH Cepu ada 360 kejadian, 22 penangkapan, 20 tersangka, jumlah pohon 684 dan kerugian ditaksir Rp. $1 \mathrm{M}$.

Data di atas menunjukkan bahwa kasus penebangan liar yang semakin meningkat dari waktu ke waktu secara pesat di Kabupaten Blora khususnya di wilayah KPH Randublatung. Serta nilai kerugian secara ekonomis yang dialami dari tahun ke tahun KPH Randublatung juga semakin meningkat.

Berdasarkan uraian di atas, penulis termotivasi untuk melakukan kajian ilmiah mengenai upaya penanggulangan dan pencegahan penebangan hutan secara liar dengan perumusan masalah sebagai berikut :

1. Mengapa penebangan liar di wilayah KPH Randublatung cenderung meningkat dari tahun ke tahun?

2. Bagaimana kebijakan penanggulangan tindak pidana penebangan liar di wilayah $\mathrm{KPH}$ Randublatung?

\footnotetext{
${ }^{87}$ Sumber Arsip KPH Randublatung, 2018.

${ }^{88}$ Ibid.
} 
3. Apa saja hambatan yang dihadapi KPH Randublatung dalam menanggulangi tindak pidana penebangan liar?

\section{METODE PENELITIAN}

Metode pendekatan yang digunakan dalam penelitian ini adalah metode pendekatan yuridis sosiologis, yang lebih bersifat kualitatif, yaitu berdasarkan data primer yang diperoleh secara langsung dari objeknya.

Penelitian ini dispesifikasikan sebagai deskriptif analistis yang bertujuan untuk memberikan gambaran dengan rinci, sistematis serta menyeluruh mengenai segala sesuatu yang berhubungan dengan masalah penyelesaian tindak pidana penebangan liar secara langsung dengan menggambarkan peraturan perundangundangan yang berlaku.

\section{HASIL PENELITIAN DAN PEMBAHASAN}

\section{Alasan Penebangan Liar di Wilayah KPH Randublatung Meningkat dari Tahun ke Tahun}

KPH Randublatung sebenarnya sudah berupaya semaksimal mungkin dalam melakukan pecegahan tindak pidana penebangan liar. Namun pada praktiknya tindak pidana penebangan liar di KPH Randublatung justru semakin meningkat dari tahun ke tahun. Hal ini disebabkan karena: ${ }^{89}$

a) Permintaan pasar terhadap kayu sangat tinggi.

Tingginya permintaan pasar yang berbanding terbalik dengan ketersediaan

\footnotetext{
89 Asep Rusnandar, "Wawancara Pribadi", Wakil Kepala Administratur KPH Randublatung, 6 Februari 2018, Pukul 12.3013.30 WIB.
}

kayu yang ada di Tempat Pelelangan Kayu (selanjutnya disebut TPK). Dalam konteks demikian bahwa permintaan kebutuhan kayu di TPK tidak mampu mencukupi tingginya permintaan kebutuhan kayu di pasar dalam negeri maupun luar negeri. Tingginya permintaan terhadap kayu di dalam negeri maupun luar negeri ini tidak sebanding dengan kemampuan penyediaan industri perkayuan. Ketimpangan antara persediaan dan permintaan kebutuhan kayu ini mendorong praktek tindak pidana penebangan liar di wilayah $\mathrm{KPH}$ Randublatung menjadi tinggi.

b) Jumlah Polisi Kehutanan tidak sebanding dengan luas hutan.

Luas areal KPH Randublatung adalah 39.033,04 hektar yang memiliki 6 (enam) BH, 12 (dua belas) BKPH, dan 44 (empat puluh empat) RPH, sementara jumlah personil polisi hutan yang ada adalah sebagai berikut: ${ }^{90}$

\begin{tabular}{|c|l|c|}
\hline No & Polisi Kehutanan & Jumlah \\
\hline 1 & Administratur & 1 \\
\hline 2 & $\begin{array}{l}\text { Wakil } \\
\text { Administratur }\end{array}$ & 2 \\
\hline 3 & Asisten Perhutani & 12 \\
\hline 4 & $\begin{array}{l}\text { Kepala Resort } \\
\text { Pemangkuan Hutan }\end{array}$ & 44 \\
\hline 5 & $\begin{array}{l}\text { Polisi Kehutanan } \\
\text { Teritorial }\end{array}$ & 9 \\
\hline 6 & $\begin{array}{l}\text { Polisi Kehutanan } \\
\text { Mobil }\end{array}$ & $\mathbf{2 1 0}$ \\
\hline & \multicolumn{1}{|c|}{ Total } \\
\hline
\end{tabular}

90 Sumber Arsip KPH Randublatung, 2018. 
Pihak-pihak yang terjun langsung dalam mengawasi dan mengamankan hutan adalah Kepala Resort Pemangkuan Hutan (selanjutnya disebut KRPH), Polisi Kehutanan Teritorial dan Polisi Kehutanan Mobil yang jumlahnya adalah 195 (seratus Sembilan puluh lima) petugas. Dibandingkan dengan luas wilayah hutan KPH Randublatung yaitu 39.033,04 hektar maka rata-rata 1 (satu) orang petugas harus mengawasi \pm 200 (dua ratus) hektar luas hutan. Belum jika terjadi tindak pidana penebangan liar jumlah petugas polisi hutan selalu kalah dengan jumlah pelaku tindak pidana penebangan liar, karena setiap terjadi tindak pidana penebangan liar pelakunya diperkirakan sampai 30 (tiga puluh) sampai dengan 80 (delapan puluh) orang. Hal tersebut tentu membuat tindak pidana penebangan liar mengalami peningkatan

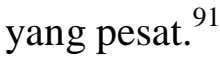

c) Ekonomi penduduk yang rendah serta banyaknya pengangguran.

Di sekitar wilayah $\mathrm{KPH}$ Randublatung tidak terdapat industri/ tempat wisata yang dapat menampung tenaga kerja. Hal ini menyebabkan angka pengangguran di wilayah tersebut relatif tinggi dibandingkan daerah lain, yang mengakibatkan ekonomi penduduk disekitar wilayah $\mathrm{KPH}$ Randublatung relatif rendah. Banyaknya pengangguran dan ekonomi yang rendah mendorong seseorang untuk melakukan suatu tindak pidana, salah satunya adalah penebangan liar. Hal ini dilakukan demi memenuhi kebutuhan hidup sehari-hari. Kondisi tersebut dimanfaatkan oleh para pemodal yang

\footnotetext{
${ }^{91}$ Ari, "Wawancara Pribadi", Staff Ajun KPH Randublatung, 12 Januari 2018, Pukul 09.0010.00 WIB.
}

tidak bertanggung jawab untuk menggerakkan penduduk sekitar untuk melakukan tindak pidana penebangan liar dengan iming-iming memperoleh keuntungan yang cepat. Pemodal yang dimaksud dalam hal ini adalah cukong yang membiayai kegiatan penebangan liar. Dari beberapa laporan yang ada para cukong terdiri dari oknum pengusaha perkayuan, oknum pejabat pemerintah, oknum Kepolisian dan Tentara Nasional Indonesia (selanjutnya disebut TNI). ${ }^{92}$

d) Pendidikan penduduk yang rendah.

Jumlah Penduduk di sekitar wilayah KPH Randublatung (Desa Mendenrejo) adalah 11.305 jiwa, ratarata memiliki jenjang pendidikan yang rendah. Berikut adalah presentase pendidikan penduduk Desa Mendenrejo

\begin{tabular}{|c|l|c|}
\hline No & $\begin{array}{c}\text { Jenis } \\
\text { Pendidikan }\end{array}$ & Presentase \\
\hline 1. & $\begin{array}{l}\text { Tidak } \\
\text { Sekolah }\end{array}$ & $9,6 \%$ \\
\hline 3. & SD & $26,7 \%$ \\
\hline 4. & SMP & $34,9 \%$ \\
\hline 5. & SMA & $21,6 \%$ \\
\hline 6. & Sarjana & $7,2 \%$ \\
\hline
\end{tabular}

Hal tersebut membuat mereka mudah di pengaruhi oleh para pemodal yang tindak bertanggung jawab untuk melakukan tindak pidana penebangan liar. Tergiur akan iming-iming hasil keuntungan yang besar menyebabkan penduduk tidak berfikir sama sekali

\footnotetext{
92 Suharta, "Wawancara Pribadi", Perwira Pembina KPH Randublatung, 30 Januari 2018, Pukul 10.30-11.30 WIB.
} 
dalam melakukan tindak pidana penebangan liar. Mereka juga tidak menyadari betapa penting dan bermanfaatnya hutan dalam kehidupan yang akan datang.

e) Lemahnya penegakan hukum terhadap pelaku tindak pidana penebangan liar.

Selama ini penegakan hukum tindak pidana penebangan penebangan liar hanya menjerat penduduk lokal saja. Mereka hanya dimanfaatkan oleh para pemodal besar yang tidak bertanggung jawab. Sedangkan untuk menjerat para pemodal besar agar ditindak dengan hukum yang berlaku cukup sulit dilakukan. Hal tersebut karena disinyalir ada indikasi keterlibatan oknum pejabat pemerintah dari dinas kehutanan, oknum kepolisian, dan oknum TNI dalam tindak pidana penebangan liar. Selain itu hukuman terhadap pelaku tindak pidana penebangan liar masih cukup ringan karena hanya mendapat hukuman penjara 3 sampai dengan 8 bulan saja yang merupakan batas minimal sanksi tindak pidana penebangan liar sebagaimana dalam ketentuan pasal 82 UU $\mathrm{P} 3 \mathrm{H}$, sehingga tidak memberikan efek jera agar tidak mengulangi perbuatannya lagi.

\section{Kebijakan Penanggulangan Tindak Pidana Penebangan Liar di Wilayah KPH Randublatung.}

\begin{tabular}{lcr} 
Pada & taraf & \multicolumn{2}{c}{ implementasi, } \\
kebijakan & penanggulangan & tindak \\
pidana penebangan liar di $\mathrm{KPH}$
\end{tabular}

Randublatung juga menggunakan 2 (dua) sarana, yaitu: ${ }^{93}$

a. Sarana Non Penal, terdiri dari 2 (dua) pola sebagai berikut :

1) Preemtif.

Pola preemtif adalah melakukan pencegahan secara dini guna menghilangkan, mengurangi, dan menutup niat seseorang atau kelompok untuk melakukan tindak pidana penebangan liar. Pelaksanaan nyata yang dilakukan oleh KPH Randublatung adalah dengan melakukan sosialisasi dan penyuluhan terhadap penduduk di kawasan hutan, melakukan patroli simpati, memberikan bantuan air bersih, bantuan kesehatan, bantuan pendidikan, serta melakukan Pengelolaan Hutan Bersama Masyarakat (selanjutnya disebut dengan PHBM), yaitu pengelolaan sumberdaya hutan yang dilakukan KPH Randublatung dan penduduk di wilayah hutan serta dengan para pihak yang berkepentingan bersama untuk mewujudkan fungsi dan manfaat sumberdaya hutan yang dapat di kelola secara optimal dan proposional.

Pada sistem PHBM dibuatkan sebuah lembaga yang disebut Lembaga Masyarakat Desa Hutan (selanjutnya disebut LMDH). LMDH adalah sebuah lembaga resmi berbadan hukum yang akan bekerjasama dengan pihak KPH Randublatung di tingkat desa yang akan yang mengikat seluruh kelompok tani hutan yang ada di desa tersebut. Anggota LMDH

93 Asep Rusnandar, "Wawancara Pribadi", Wakil Kepala Administratur KPH Randublatung, 6 Februari 2018, Pukul 12.30-13.30 WIB. 
adalah para penggarap yang tergabung dalam kelompok tani hutan serta penduduk yang yang peduli terhadap kelestarian dan keberadaan hutan.

2) Preventif

Pola preventif ditujukan guna mencegah, menghilangkan, mengurangi, dan menutup kesempatan seseorang atau kelompok untuk melakukan tindak pidana penebangan liar.

Pelaksanaan nyata yang dilakukan oleh KPH Randublatung adalah sebagai berikut:

a) Melakukan patroli pengamanan hutan, yaitu melakukan pengawasan yang dilakukan dengan cara bergerak dari satu tempat ke tempat lainnya yang di anggap rawan tindak pidana penebangan liar oleh 2 (dua) sampai 3 (tiga) orang atau lebih yang mempunyai taggung jawab mengamankan wilayah hutannya. Jenis patroli yang dilakukan adalah patroli rutin, patroli jalan raya, patroli mobil yang dilakukan secara intern maupun gabungan dengan Kepolisian atau Tentara Nasional Indonesia (selanjutnya disebut TNI).

b) Melakukan penjagaan pengamanan hutan, yaitu melakukan penjagaan di pospos jaga yang telah disediakan dan di tentukan yang penempatannya berdasarkan pata titik rawan terjadinya tindak pidana penebangan liar yang dilakukan 24 jam.

c) Pembangunan kelembagaan (Capacity Building) dengan memberikan pembinaan dan pemahaman yang baik tentang bagaimana cara penanggulangan tindak pidana penebangan liar, membangun kedisiplinan dan kekompakan antar personil, memberikan pelatihan Kesamaptaan dengan melakukan sosialisasi dan penyegaran fisik untuk meningkatkan kemampuan dan ketrampilan setiap anggota polisi kehutanan dan pelatihan beladiri praktis agar selalu siap siaga dalam mengatasi tindak pidana penebangan liar, serta memberikan reward and punishment.

b. Sarana Penal dengan menggunakan Pola Represif.

Kegiatan represif merupakan kegiatan dengan sarana penal. Penegakan hukum yang bersifat non yustisia untuk mengurangi, menekan atau menghentikan tindak pidana kehutanan yang dilakukan oleh seseorang atau kelompok. Pelaksaaan nyata yang sudah dilakukan oleh KPH Randublatung adalah sebagai berikut:

1) Melakukan operasi penegakan hukum;

2) Melakukan pengumpulan bahan keterangan hasil laporan dari penduduk sekitar wilayah KPH Randublatung;

3) Melakukan pengamanan barang bukti dari hasil tindak pidana penebangan liar; 
4) Melakukan pengawalan terhadap pelaku, saksi dan barang bukti tindak pidana penebangan liar.

\section{Hambatan yang Dihadapi KPH Randublatung dalam Menanggulani Tindak Pidana Penebangan Liar}

Dalam upaya penanggulangan tindak pidana penebangan huta secara liar KPH Randublatung mengalami hambatan, yaitu: ${ }^{94}$

\section{a. Hambatan Internal}

1) Sarana dan prasarana yang dimiliki oleh pihak KPH Randublatung untuk menangani tindak pidana penebangan liar masih terbatas, antara lain : mobil patrol polhut roda 4 ada 2 , mobil patrol truk roda 6 ada 1 , motor trail ada 57, tongkat rotan ada 120, tongkat cabang ada 5, sangkur ada 7, alat kejut ada 5, serta borgol yang berjumlah hanya $7 .^{95}$

2) Kurangnya jumlah petugas untuk menjaga dan mengawasi hutan. Luas areal KPH Randublatung adalah 39.033,04 hektar yang memiliki 6 (enam) BH, 12 (dua belas) BKPH, dan 44 (empat puluh empat) RPH. Jumlah tersebut tidak sebanding dengan jumlah petugas yang ada, yaitu hanya 210 (dua ratus sepuluh) petugas, yang hanya 195 (seratus sembilan puluh lima) petugas yang aktif melakukan pengawasan dan

94 Asep Rusnandar, "Wawancara Pribadi", Wakil Kepala Administratur KPH Randublatung, 6 Februari 2018, Pukul 12.3013.30 WIB.

${ }^{95}$ Sumber Arsip KPH Randublatung, 2018. pengamanan terhadap hutan. Hal tersebut dapat dibayangkan 1 (satu) orang polisi hutan harus mengawasi \pm 200 (dua ratus) hektar luas hutan. Apabila terjadi tindak pidana penebangan liar jumlah petugas selalu kalah dari pelaku tindak pidana penebangan liar sehingga hal tersebut menghambat untuk mengamankan hutan yang ada di wilayah KPH Randublatung. ${ }^{96}$

3) Penarikan senjata api milik Polisi kehutanan oleh pihak Kepolisian. Penarikan tersebut dilakukan atas dasar prinsip kehati-hatian mengingat Polisi kehutanan belum dibekali serangkaian pelatihan khusus. Untuk dapat memiliki dan menggunakan senjata api, seseorang harus terlebih dahulu menjalani serangkaian tes yang sangat panjang. Hal ini bertujuan agar senjata tersebut tidak disalahgunakan yang berakibat dapat membahayakan diri sendiri maupun orang lain. Namun demikian penarikan tersebut juga memiliki kelemahan, yaitu melemahkan para petugas dari $\mathrm{KPH}$ randublatung dalam mengamankan wilayah hutannya, mengingat tindak pidana penebangan liar selalu dilakukan oleh orang banyak dan kejadiannya tidak dapat di prediksi sebelumnya;

\section{b. Hambatan Eksernal}

1) Akses jalan di wilayah hutan KPH Randublatung yang sangat

96 Ari, “Wawancara Pribadi”, Staff Ajun KPH Randublatung, 12 Januari 2018, Pukul 09.00-10.00 WIB. 
sulit dilalui juga menjadi faktor penghambat memberantas tindak pidana penebangan liar. Hal tersebut karena memang faktor alami wilayah hutan, belum lagi jika pada musim hujan jalan terkadang tidak dapat dilalui kendaraan. Akses jalan yang sulit dalam upaya preventif menyulitkan polisi hutan dalam menjangkau seluruh wilayah hutan yang sangat luas. Dalam upaya represif menyulitkan polisi hutan yang akan menangkap para pelaku tindak pidana penebangan liar. Sebagai contoh ketika ada peristiwa penebangan liar, sulitnya medan menyebabkan keterlambatan polisi hutan dalam menangkap para pelaku, sehingga ketiga polisi hutan sampai di lokasi para pelaku sudah terlebih dahulu melarikan diri ;

2) Masih lemahnya koordinasi dalam penanganan tindak pidana penebangan liar dengan pihakpihak terkait seperti Kepolisian, TNI dan Dinas terkait. Hal ini terjadi karena masing-masing pihak belum memiliki kesepahaman dalam penanganan perkara, dimana oknum kepolisian berpendapat bahwa tidak semua perkara harus dilimpahkan ke Kepolisian melainkan dapat diselesaikan di tingkat KPH Randublatung, sementara oknum pihak KPH Randublatung berpendapat bahwa perkara tersebut memang wewenang pihak Kepolisian. Kondisi demikan terkonfirmasi dengan belum adanya aturan baku mengenai batasan kewenangan masing-masing pihak.

3) Masyarakat sekitar sulit untuk diajak komunikasi. Berdasarkan keterangan Sukandar selaku Kepala Desa Mendenrejo, bahwa ketika didekati oleh pihak KPH Randublatung baik melalui kegiatan sosialisasi, penyuluhan maupun pemberian bantuan, masyarakat sekitar masih menghindar dan cenderung sulit diajak komunikasi. Hal ini dikarenakan adanya anggapan yang salah dari masyarakat bahwa upaya pihak KPH tersebut bertujuan untuk memata-matai dan menandai masyarakat tertentu sebagai pelaku tindak pidana penebangan liar. ${ }^{97}$

\section{Kesimpulan}

Berdasarkan pembahasan di atas, dapat disimpulkan sebagai berikut :

a) Tindak pidana penebangan liar di wilayah KPH Randublatung meningkat dari tahun ke tahun disebabkan karena :

1) Permintaan pasar terhadap kayu sangat tinggi.

2) Jumlah Polisi Kehutanan tidak sebanding dengan luas hutan.

3) Ekonomi penduduk yang rendah serta banyaknya pengangguran.

4) Pendidikan penduduk yang rendah.

5) Lemahnya penegakan hukum terhadap pelaku tindak pidana penebangan liar.

b) Kebijakan penanggulangan tindak pidana penebangan liar di wilayah

97 Sukandar, “Wawancara Pribadi”, Kepala Desa Mendenrejo, 12 Februari 2018, Pukul 16.30-17.30 WIB. 
$\mathrm{KPH}$ Randublatung dilakukan dengan 2 sarana, yaitu sarana non penal dan sarana penal.

1) Sarana non penal terdiri dari 2 pola, yaitu;

a. Preemtif yaitu dengan melakukan sosialisasi dan penyuluhan terhadap penduduk di kawasan hutan, melakukan patroli simpati, memberikan bantuan air bersih, bantuan kesehatan, bantuan pendidikan, serta melakukan Pengelolaan Hutan bersama masyarakat.

b. Preventif yaitu dengan melakukan patroli pengamanan hutan, melakukan penjagaan pengamanan hutan, pembangunan kelembagaan dengan memberikan pembinaan dan pemahaman yang baik.

2) Sarana Penal berupa pola represif dengan melakukan operasi penegakan hukum, melakukan pengumpulan bahan keterangan hasil laporan dari penduduk sekitar wilayah KPH Randublatung, melakukan pengamanan barang bukti dari hasil tindak pidana penebangan liar dan melakukan pengawalan terhadap pelaku, saksi dan barang bukti tindak pidana penebangan liar.

c) Hambatan yang dihadapi $\mathrm{KPH}$ Randublatung dalam menanggulangi tindak pidana penebangan liar terdiri dari hambatan internal dan hambatan eksternal.

1) Hambatan internal yaitu:

a. Terbatasnya sarana dan prasarana yang dimiliki oleh pihak

$\mathrm{KPH}$

Randublatung,

b. Kurangnya jumlah petugas untuk menjaga dan mengawasi hutan,

c. Penarikan senjata api milik Polisi kehutanan oleh pihak Kepolisian.

2) Hambatan eksternal yaitu:

a. Akses jalan di wilayah hutan KPH Randublatung yang sangat sulit dilalui.

b. Masih lemahnya koordinasi dalam penanganan tindak pidana penebangan liar dengan pihak-pihak terkait.

c. Masyarakat sekitar yang sulit diajak komunikasi.

\section{Saran}

Berdasarkan kesimpulan yang telah dikemukakan di atas, maka penulis memberikan saran sebagai berikut :

a. KPH Randublatung sebaiknya mengoptimalkan pengelolaan hutan dengan membuat objek wisata di wilayah hutan, agar dapat menampung tenaga kerja masyarakat sekitar terutama mantan pelaku dan/atau terindikasi pelaku. Sehingga dengan adanya wisata akan meningkatkan perekonomian masyarakat sekitar.

b. Optimalisasi sarana penal dan sarana non penal dalam penanggulangan tindak pidana penebangan liar, yakni:

1) Dalam sarana penal yang menggunakan pola represif diharapkan hakim dalam menjatuhkan putusan tidak menggunakan batas minimal yang tercantum dalam ketentuan pasal 82 UU P3H melainkan menggunakan batas maksimal 
dalam ketentuan dimaksud. Hal ini mengingat angka terjadinya tindak pidana penebangan liar di wilayah hutan KPH Randublatung selalu meningkat dari tahun ke tahun.

2) Dalam sarana non penal terdapat pola preemtif dan pola preventif.

a) Dalam pola preemtif diharapkan KPH Randublatung semakin meningkatkan atau menambah porsi kegiatan sosialisasi dan penyuluhan yang sebelumnya belum dilakukan secara rutin agar dapat dilakukan secara rutin setidaknya sebulan sekali dengan lebih menyasar kepada mantan pelaku dan/atau yang terindikasi pelaku.

b) Dalam pola preventif diharapkan KPH Randublatung menambah jumlah personil polisi kehutanan / tenaga pengawas yang berintegritas agar pengawasan wilayah hutan lebih optimal.

c. Dalam rangka menyelesaikan hambatan internal dan hambatan eksternal perlu dilakukan hal-hal sebagai berikut:

1) Secara internal ada penambahan jumlah sarana prasarana sesuai dengan yang dibutuhkan oleh KPH
Randublatung, serta mengikutsertakan petugas polisi kehutanan KPH Randublatung dalam serangkaian pelatihan dan tes untuk memperoleh izin menggunakan senjata api.

2) Secara eksternal adalah dengan memperbaiki pola komunikasi dan kordinasi antar pihak KPH Randublatung dengan pihak Kepolisian, TNI serta Dinas Kehutanan agar kedepannya terjalin hubungan yang saling melengkapi, sehingga penanganan tindak pidana penebangan liar dapat lebih optimal.

\section{DAFTAR PUSTAKA}

Supranto, 2003, "Metode Penelitian Hukum dan Statistik”, Rineka Cipta, Jakarta.

Soerjono Soekanto, 1986, "Pengantar Penelitian Hukum”, UI Press, Jakarta.

Ronny Hanitijo Soemitro, 1983, "Metode Penelitian Hukum dan Jurimetri”, Ghalia Indonesia, Jakarta

Mardalis, 2008, “Metode Penelitian Suatu Pendekatan Proposal”, Bumi Aksara, Jakarta. 